\title{
Milk: an exosomal microRNA transmitter promoting thymic regulatory $T$ cell maturation preventing the development of atopy?
}

\author{
Bodo C Melnik ${ }^{1 *}$, Swen Malte John ${ }^{1}$ and Gerd Schmitz ${ }^{2}$
}

\begin{abstract}
Epidemiological evidence confirmed that raw cow's milk consumption in the first year of life protects against the development of atopic diseases and increases the number of regulatory T-cells (Tregs). However, milk's atopyprotective mode of action remains elusive.

This review supported by translational research proposes that milk-derived microRNAs (miRs) may represent the missing candidates that promote long-term lineage commitment of Tregs downregulating IL-4/Th2-mediated atopic sensitization and effector immune responses. Milk transfers exosomal miRs including the ancient miR-155, which is important for the development of the immune system and controls pivotal target genes involved in the regulation of FoxP3 expression, IL-4 signaling, immunoglobulin class switching to IgE and FcERI expression. Boiling of milk abolishes milk's exosomal miR-mediated bioactivity. Infant formula in comparison to human breast- or cow's milk is deficient in bioactive exosomal miRs that may impair FoxP3 expression. The boost of milk-mediated miR may induce pivotal immunoregulatory and epigenetic modifications required for long-term thymic Treg lineage commitment explaining the atopy-protective effect of raw cow's milk consumption.

The presented concept offers a new option for the prevention of atopic diseases by the addition of physiological amounts of miR-155-enriched exosomes to infant formula for mothers incapable of breastfeeding.
\end{abstract}

Keywords: Atopy prevention, DNA demethylation, Exosome, FoxP3, MicroRNA, Milk, MiR-155, Regulatory T cell

\section{Introduction}

Children who grow up on traditional farms are protected from atopic diseases [1]. Early-life consumption of unboiled cow's milk has been identified as the most protective factor for the development of atopy [2-10]. Farm milk exposure has been associated with increased numbers of $\mathrm{CD} 44^{+} \mathrm{CD} 25^{+} \mathrm{FoxP} 3^{+}$regulatory $\mathrm{T}$ cells (Tregs), lower atopic sensitization and asthma in 4.5-year-old children [11]. Treg cell numbers are negatively associated with asthma and perennial IgE levels [11]. However, potential effectors of milk, which stimulate the development of Tregs remain elusive. This review provides translational evidence that milk-derived exosomal microRNAs may be the potential stimuli for thymic Treg maturation and raw milk-mediated atopy prevention.

\footnotetext{
* Correspondence: melnik@t-online.de

${ }^{1}$ Department of Dermatology, Environmental Medicine and Health Theory, University of Osnabrück, Sedanstrasse 115, D-49090 Osnabrück, Germany Full list of author information is available at the end of the article
}

\section{Atopic diseases are associated with reduced Treg numbers}

Atopic allergy is a Th2 cell-mediated disease that involves the formation of specific IgE antibodies against innocuous environmental substances. Both naturally occurring thymus-derived and inducible Tregs of the periphery prevent allergy development via suppression of Th2 cells [12-14]. Decreased FoxP3 ${ }^{+}$Treg numbers have been detected in atopic mothers at the $34^{\text {th }}$ week of gestation, in cord blood in association with high IgE levels, in sputum, nasal secretions and blood of atopic patients pointing to the pivotal role of $\mathrm{FoxP}^{+}$Tregs in the immunopathogenesis of atopy [15-18].

Scurfy is an X-linked recessive severe murine autoimmune disease resulting from a Foxp3 mutant [18]. The human analog is the immune dysregulation, polyendocrinopathy, enteropathy, X-linked (IPEX) syndrome associated with eczema and increased IgE levels caused by impaired function of Tregs due to mutated FOXP3 
[19]. In the X-linked immunodeficiency disorder WiskottAldrich syndrome (WAS) the mutated WAS protein (WASP) plays the key role in impaired Treg suppressor function [20,21]. WASP knockout mice display decreased numbers of Treg cells in both the thymus and peripheral lymphoid organs [22]. Tregs control the severity of anaphylaxis [23], contribute to the resolution of Der p1induced allergic airway inflammation [24], and inhibit allergen-specific effector cells important for the successful outcome in allergen-specific immunotherapy [25]. Thus, Tregs are central players in the pathogenesis and treatment of atopy $[26,27]$.

\section{Thymic maturation of natural regulatory $\mathrm{T}$ cells}

The vast majority of Tregs is generated in the thymic medulla at the $\mathrm{CD}^{+}$single-positive stage of thymocyte development [28,29]. Tregs highly express FoxP3, the master regulator for Treg cell differentiation and function [30-32]. Whereas naturally occurring Tregs are educated in the thymus, inducible Tregs can be generated in the periphery $[26,33-41]$. FoxP3 ${ }^{+} \mathrm{T}$ cells are detectable in the periphery 3 days after birth during the period of colostrum feeding [26]. Hassall's corpuscles in the thymic medulla secrete thymic stromal lymphopoietin (TSLP) that activates $\mathrm{CD} 11 \mathrm{c}^{+}$dendritic cells (DCs), which induce Foxp3 expression in immature $\mathrm{CD} 4^{+} \mathrm{CD} 8^{-} \mathrm{CD} 25^{-}$ thymocytes [42,43]. Crucial for FoxP3 induction are early signals from the $\mathrm{T}$ cell receptor (TCR), interleukin2 (IL-2), transforming growth factor- $\beta$ (TGF- $\beta$ ), and Notch1 [44,45] (Figure 1).

Role of microRNAs in thymic FoxP3 ${ }^{+}$Treg cell maturation MicroRNAs (miRs) are fundamental regulators of posttranscriptional programs that play a role in maturation and differentiation of Tregs in the thymus [46-49]. Substantial evidence underlines that miR-155 is required for the development of the Treg lineage [47]. MiR-155deficient mice have reduced numbers of Tregs both in the thymus and periphery [47]. FoxP3, which is highly expressed in Tregs, binds to the promoter of bic, the gene encoding miR-155 [40,50,51]. TCR and Notch signaling upregulates the IL-2R $\alpha$-chain (CD25), rendering thymocytes receptive to subsequent cytokine signals that foster their development into fully functional FoxP3 ${ }^{+}$ Tregs [52-54]. IL-2 is capable of transducing signals in $\mathrm{CD}^{+}{ }^{+}$FoxP3 $^{+}$Tregs as determined by STAT5 phosphorylation [54]. Deletion of miR-155 results in limited IL-2/ STAT5 signaling and reduced Treg numbers [55]. Remarkably, miR-155 enhances FoxP3 expression by targeting suppressor of cytokine signaling 1 (SOCS1), an important negative regulator of IL-2R/STAT5 signaling (Figure 1). MiR-146a targets STAT1 and regulates Treg-

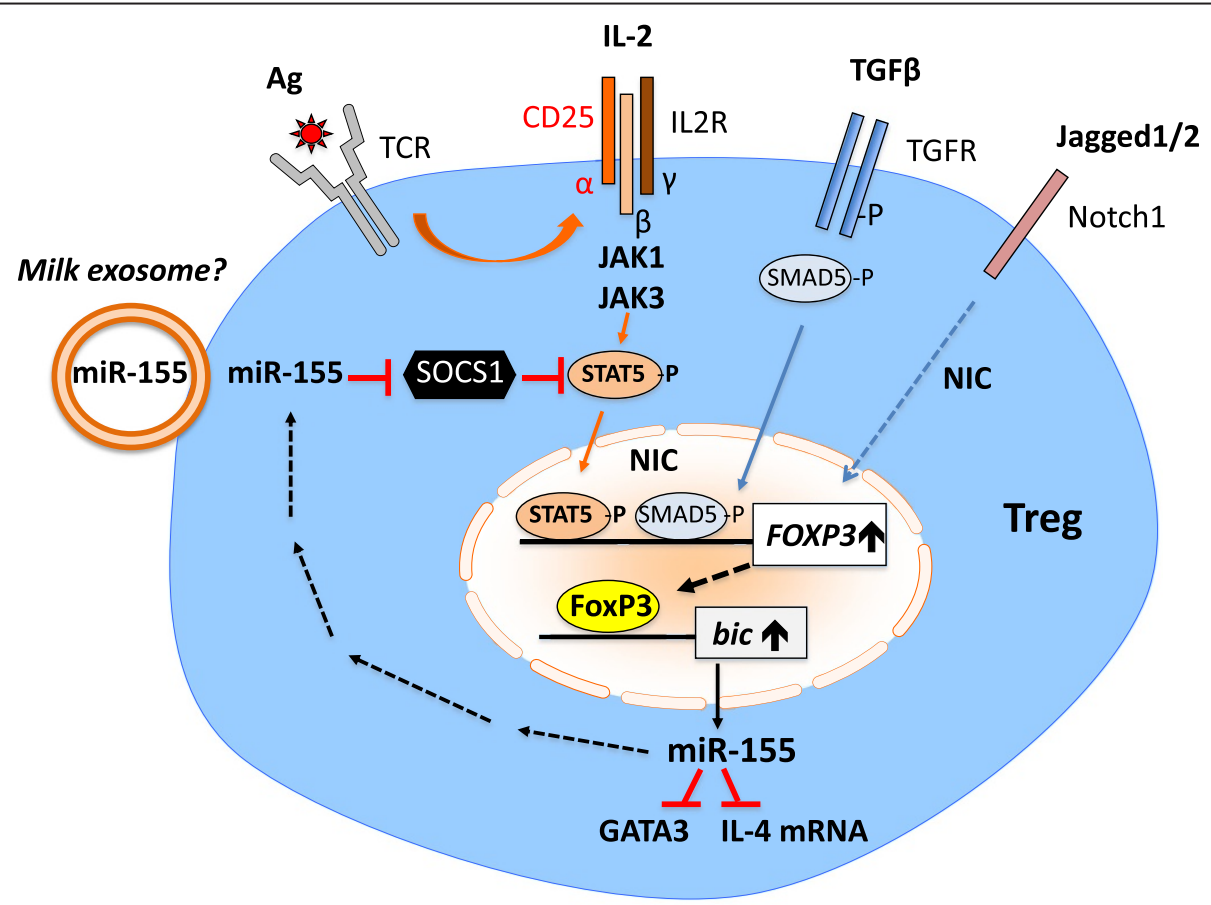

Figure 1 Potential mechanisms of milk exosome miR-155-mediated FoxP3 expression in Tregs. TCR activation upregulates CD25 and subsequent IL-2/STAT5 signaling, which cooperatively with TGF 3 -activated SMAD5 stimulate the FOXP3 promoter. MiR-155 attenuates the expression of SOCS1, the inhibitor of STAT5, thus amplifying IL-2/STAT5-mediated FoxP3 expression. FoxP3 activates the bic promoter enhancing the synthesis of miR-155, which suppresses mRNAs of GATA3 and IL-4, pivotal transcription factors of Th2-mediated IgE-driven atopic immune responses. 
mediated suppression function and maintains Treg identity [48]. Deletion of miR-146a in Tregs causes a severe autoimmune phenotype akin to Dicer knockout animals, characterized by increased numbers of poorly functional FoxP3 $^{+}$Tregs in the periphery [56]. MiR-21 is highly expressed in Tregs and positively regulates FOXP3 [57]. MiRs are processed in the cytoplasm by the ribonuclease Dicer. Conditional knockout of Dicer in $\mathrm{CD}^{+}{ }^{+}$cells results in depletion of thymic Tregs and suppressed TGF- $\beta$ mediated induction of Foxp3 in naïve $C D 4^{+}$cells associated with increased IL-4 levels [50]. Dicer knockout mice as well as mice with conditional knockout of Dicer in FoxP3 $^{+}$cells develop severe autoimmune diseases [58,59]. In the later model, FoxP3 expression is unstable and Treg revert to an effector phenotype producing IL-4 and IFN- $\gamma$. Notably, miR-155 negatively regulates mRNA levels of GATA-3 and IL-4 [60]. It is well known that GATA-3 promotes Th2 responses [61]. In miR-155 null mice increased Th2 cell differentiation has been reported $[62,63]$.

\section{Exosomal microRNAs in immune cell communication}

Valadi et al. [64] were the first who demonstrated that exosome-mediated transfer of mRNAs and microRNAs is a novel mechanism of genetic exchange between cells. Secreted miRs represent a newly recognized layer of gene regulation and intercellular communication [65-67]. MiRs bind through partial sequence homology to the 3'untranslated region of target mRNAs and cause either translational block or mRNA degradation [68]. Exosomal miRs, enclosed by membranous microvesicles, play a pivotal role for horizontal miR transfer [69]. Raposo et al. [70] provided first evidence for exosome-mediated immune cell communication. Unidirectional transfer of miRloaded exosomes from $\mathrm{T}$ cells to antigen-presenting cells has recently been confirmed [71]. For immune cell-cell interactions exosome transport exchanging genetic messages over distances has been demonstrated [72,73]. In the human thymic medulla miR-transporting exosomes that may provide genetic signals required for Treg formation have recently been characterized [74].

\section{Milk-derived exosomal miRs: boosters for thymic Treg maturation?}

Recently, we have suggested that milk is an endocrine signaling system that promotes mTORC1 signaling by transfer of essential branched-chain amino acids and exosomal regulatory miRs to the milk recipient [75]. Zhang et al. [76] published that diet-derived plant MIR168a reaches the plasma compartment of human subjects and affects LDLRAP1 metabolism in the liver [76]. However, Dickinson et al. [77] were unable to detect plant miRs after feeding in mice. Breast milk in comparison to all other body fluids contains the highest amounts of total RNAs [78]. Bovine and human milk contain substantial amounts of exosomal
miRs that may be transferred to the infant to promote immune regulatory functions [79-81]. MiR-containing exosomes of 30-100 $\mathrm{nm}$ diameter have been identified in human breast milk, cow's milk, bovine whey and colostrum [83-85]. Exosomes from bovine colostrum and mature milk are able to deliver miRs into cultured cells thereby increasing cytoplasmic miR levels [85]. Although not proven yet, several investigators regard milk-derived miRs as important effectors for the development of the infant's immune system and proposed that milk's miRs may reach the infant's circulation and organ systems [81,85-87]. Admyre et al. [82] demonstrated that incubation of human PBMCs with isolated human milk exosomes increased the number of CD4 ${ }^{+} \mathrm{CD} 25^{+} \mathrm{FoxP}^{+}$Tregs in a dose-dependent manner. $\mathrm{Hu}-$ man and bovine milk contain significant amounts of those immune regulatory miRs (miR-155, miR-146a, miR-21) that play a known role in thymic Treg differentiation $[80,81,85,87]$. Bovine colostrum in comparison to mature milk contains the highest amounts of miR155 and miR-21 [80,81]. Substantial exosomal miR-155 content has been detected in bovine whey [81]. The lipid bilayer of milk exosomes protects their miR-cargo against harsh degrading conditions like low acidic $\mathrm{pH}$ of 1-2 and RNase-mediated degradation $[81,86]$. Boiling of milk, however, results in complete miR degradation [87]. Raw cow's milk contains the highest amounts of bioactive miRs, whereas pasteurized milk contains lower levels and milk powder used for infant formula production only exhibits trace amounts of detectable RNAs $[80,81]$.

\section{Milk exosome CD81: an exosomal antigen required for thymocyte maturation?}

The increased intestinal permeability during the postnatal period may support milk exosome traffic into the infant's blood circulation. Intestinal cells release exosomes of 30$90 \mathrm{~nm}$ in diameter from their apical and basolateral sides [87]. Milk exosomes are specifically characterized for the presence of CD81, CD63 and Hsc70 and the absence of calnexin [83]. The tetraspanins CD81 and CD63 are also present on intestinal cell-derived exosomes [88] and circulating exosomes in human plasma [89]. Blood is regarded as a physiological fluid for exosome circulation in the body supporting exosome traffic for cell-cell and organorgan communications [67,71-73,90]. Importantly, exosomes have been observed in murine and human thymus [74,91]. Milk exosomes and thymic exosomes are of comparable size and contain TSG101, CD81, CD63 and milk fat globulin (MFG)-8 [74,83,91-93]. A monoclonal antibody against CD81 blocked the appearance of $\alpha \beta$ T cells in fetal murine thymic organ cultures. In reaggregation cultures with CD81-transfected fibroblasts, CD4 CD8 ${ }^{-}$ thymocytes differentiated into $\mathrm{CD} 4^{+} \mathrm{CD}^{+} \mathrm{T}$ cells. Thus, 
interaction between immature thymocytes and CD81 is required for the transition of thymocytes from the CD4$\mathrm{CD}^{-}$to the $\mathrm{CD}^{+}{ }^{+} \mathrm{CD} 8^{+}$stage [93]. CD81 of thymic stromal cells but also milk exosome-derived CD81 may play a role in CD81-mediated thymocyte development.

\section{Milk- and thymus-derived exosomes promote Treg maturation}

MiR-155 exhibits highest expression in colostrum and is still a predominant exosomal miR of bovine whey $[84,85]$. MiR-155, miR-146a and miR-21 are components of human plasma $[86,94,95]$. Human and bovine milk exosomes are taken up by macrophages and thereafter increase cellular miR levels [85,92]. Notably, isolated human breast milk exosomes incubated with human PBMCs increase $\mathrm{CD} 4{ }^{+} \mathrm{CD} 25^{+} \mathrm{FoxP}^{+}$Treg numbers [82]. Intriguingly, murine thymic exosomes induce the conversion of $\mathrm{CD} 4{ }^{+} \mathrm{CD} 25^{-}$thymic $\mathrm{T}$ cells into $\mathrm{CD} 4{ }^{+} \mathrm{CD} 25$ ${ }^{+}$FoxP3 ${ }^{+}$Tregs in a dose-dependent manner [91]. Thus, both human breast milk exosomes and thymic exosomes are able to induce $\mathrm{CD} 4^{+} \mathrm{CD} 25^{+} \mathrm{FoxP}^{+}$Tregs [82,91]. We thus propose that milk may function as a miR messenger system boosting thymic Treg cell maturation by transfer of milk-derived exosomes donating miRs required for appropriate thymic Treg maturation by the evolutionarily conserved process of breastfeeding. Notably, phylogenetic studies demonstrate that miR-155 is conserved across species [96]. There is a high homology between human (hsa-mir-155) and bovine miR-155 (bta-mir-155) (www.mirbase.org).

\section{MiR-mediated FOXP3 demethylation}

Farm milk exposure increases the numbers of demethylated $\mathrm{CD}^{+}{ }^{+} \mathrm{CD} 25^{+} \mathrm{FoxP}^{+}$Tregs [11]. Stable expression of Foxp3 in Tregs depends on DNA demethylation at the Treg-specific demethylated region (TSDR), a conserved, CpG-rich region within the FOXP3 locus [97]. Binding of the transcription factor Ets-1 to the demethylated Foxp3 gene stabilizes Foxp3 expression in Tregs [98] (Figure 2). Atopic individuals express lower numbers of demethylated FoxP3 ${ }^{+}$Tregs [99]. DNA methylation is often associated with inhibition of transcriptional activity and plays a fundamental role during development and genomic imprinting [100]. Milk, the "starter cocktail" of postnatal mammalian life, may function as an epigenetic regulator for thymic Treg maturation. There are two potential mechanisms of DNA demethylation: 1) passive demethylation through inhibition of DNA methyltransferases (DNMTs) and 2) active demethylation mediated by ten-eleven-translocation (TET) 2 and 3 [100]. TET2 binding to CpG-rich regions requires the interaction of TET2 with the protein IDAX (also known as CXXC4) [101]. Intriguingly, the CXXC DNA-binding domains can bind unmethylated DNA and recruit TET2 via IDAX [102]. Both DNMT1 and DNMT3b are associated with the Foxp3 locus in $\mathrm{CD}_{4}^{+}$
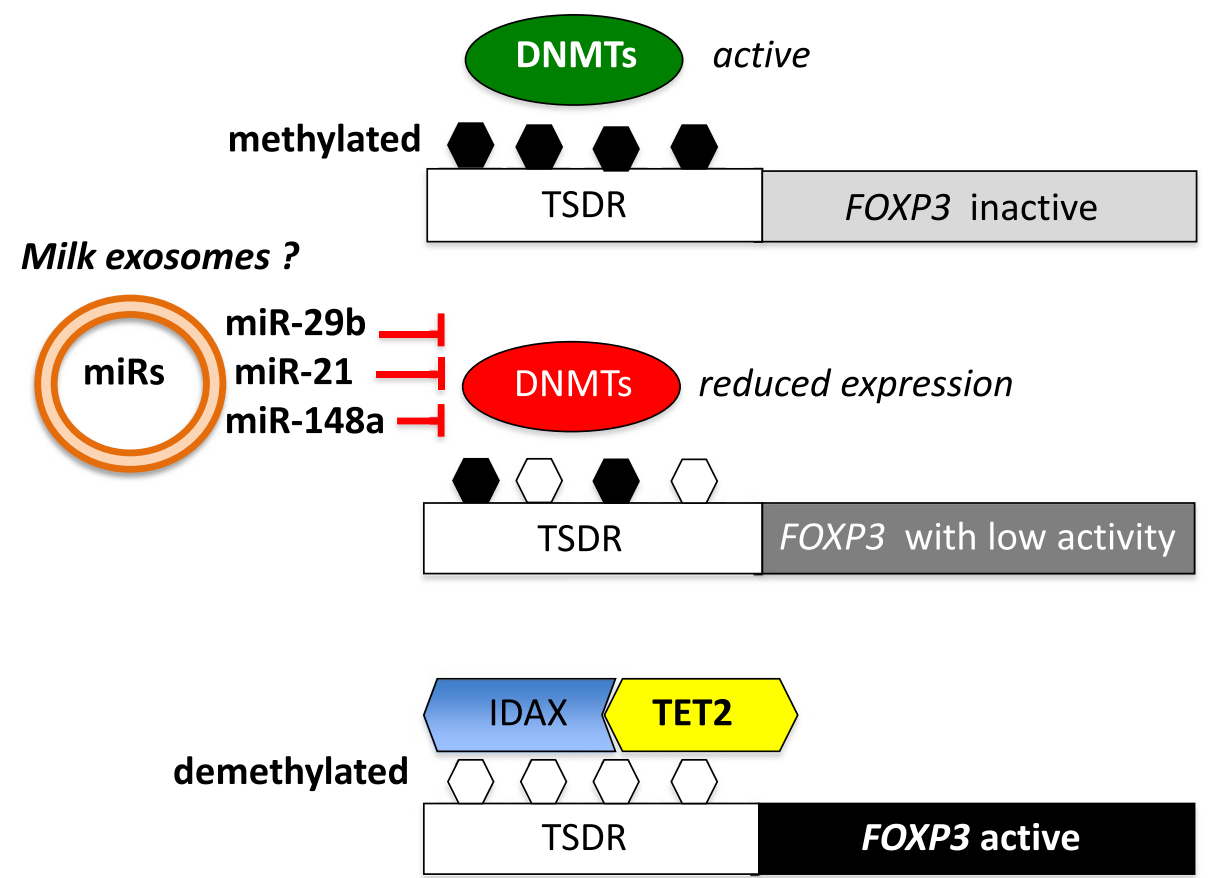

Figure 2 Proposed mode of action of milk miR-mediated demethylation of FOXP3. Milk-derived miR-29b, -21, and -148a may reduce the expression of DNMTs resulting in TSDR hypomethylation required for IDAX binding, which finally attracts TET2 to the TSDR resulting in complete TSDR demethylation, important for permanent FOXP3 stabilization. 
cells [103]. Methylation of CpG residues represses Foxp3 expression, whereas complete demethylation is required for stable Foxp3 expression [103]. There is increasing evidence that miRs modify the regulatory network of TET2 expression [104]. MiR-21 indirectly down-regulates DNMT1 by targeting ras guanyl nucleotide-releasing protein 1 (RASGRP1). MiR-148a, a highly expressed miRspecies in colostrum and mature milk $[80,81,87]$, directly targets DNMT1 expression [105]. MiR-29b, another miR species of milk [81], contributes to DNA hypomethylation of $\mathrm{CD}^{+}{ }^{+} \mathrm{T}$ cells in systemic lupus erythematosus indirectly targeting DNMT1 [106]. Milk-miR-mediated hypomethylation of CpG-regions of the TSDR FOXP3 locus may thus promote the final step of active TSDR demethylation. In fact, IDAX-mediated TET2 binding results in complete and permanent FOXP3 demethylation. TSDR demethylation occurs during the CD4-single positive stage of thymocytes and the presence of 5-hydroxymethylcytosine (5-hmC), a product of TET-mediated $5 \mathrm{mC}$ hydroxylation, within the TSDR region and the induction of TET2/3 during Treg maturation points to active TET-mediated demethylation of FOXP3 TSDR [97]. We thus speculate that the immunoregulative miR network of milk may induce lineage-specific epigenetic modifications of FOXP3 required for long-term Treg lineage stability and atopy prevention.

\section{MiR-155 and atopy-related target genes}

MiR-155 inhibits suppressor of cytokine signaling 1 (SOCS1) [60]. SOCS1 is a negative regulator of phosphorylated STAT5. TCR, IL-2 and TGF- $\beta 1$ are pivotal signals for Treg differentiation associated with phosphorylation of STAT5 and SMAD5, which enhance FoxP3 expression. MiR-155-mediated suppression of SOCS1 augments FoxP3 expression promoting further miR-155 synthesis [47] (Figure 1).
The transcription factor c-Maf promotes IL-4 expression and is induced during normal precursor cell differentiation along the Th2 lineage $[107,108]$. c-Maf binds to the c-Maf response element in the proximal IL-4 promoter (Figure 3A). Importantly, c-Maf is a target of miR-155 $[62,109]$. In accordance, $C D 4^{+}$cells transfected with antimiR-155 expressed higher levels of GATA-3 and IL-4 [60]. Thus, miR-155-mediated c-Maf suppression promotes FoxP3 $^{+}$Treg activity and impairs IL-4/Th2 cell-mediated atopic immune deviations (Figure 3B).

The lipid phosphatase SHIP1 (Src homology-2 domaincontaining inositol 5-phosphatase 1) plays an increasing role for immune regulation [110,111]. Myeloid-specific ablation of SHIP leads to the expansion of Treg cell numbers, confirming the role of SHIP in the control of Treg numbers [112]. Notably, SHIP1 mRNA is a primary target miR-155 [113].

The transcription factor PU.1 is a direct target of miR155 and is involved in the regulation of immunoglobulin (Ig) class-switch of plasma cells [114]. Ig heavy chain class switching to IgE is directed by IL- 4 and IL-13 by inducing transcription from the IgE germline promoter [115]. IL-4-induced IgE germline gene transcription represents an early step during IgE isotype switch differentiation and is orchestrated by the coordinated action of the transcription factors STAT6, PU.1, NF-kB, and C/ $\mathrm{EBP}$ on the promoter region of the IgE germline gene [115-117]. MiR-155-mediated suppression of PU.1 and c-Maf may thus attenuate IL-4-induced IgE synthesis. Notably, PU.1 cooperatively with GATA-1 transactivates the $\alpha$-chain of the high affinity receptor of IgE (FceRI) [118]. FceRI plays an important role in IgE-mediated atopic sensitization as well as in IgE-mediated atopic immune reactions.

Cytotoxic T lymphocyte-associated antigen-4 (CTLA-4) is a surface molecule of activated $\mathrm{T}$ cells and a negative regulator of $\mathrm{T}$-cell activation. The mean percentage of $\mathrm{T}$

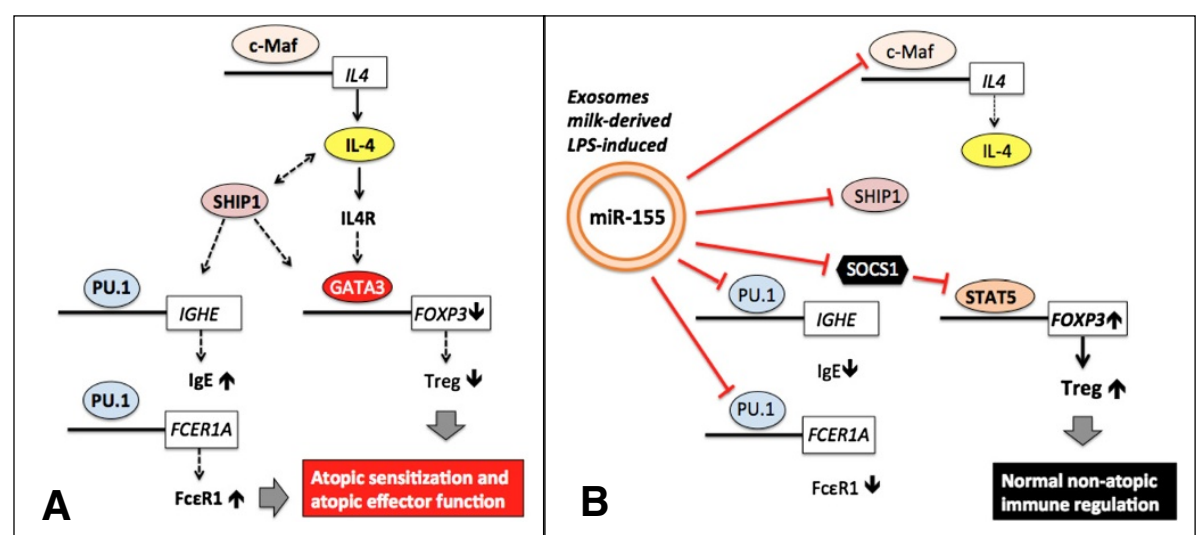

Figure 3 Impact of miR-155 on immune regulating transcription factors. A) atopic immune deviations in the absence of miR-155 and B) non-atopic development of the immune system due to appropriate miR-155 signaling. 
cells expressing CTLA-4 in patients with atopic dermatitis was higher than in the control group [119]. miR-155 was identified as a direct target of CTLA-4 [120]. CTLA-4 has been shown in mice to control Foxp3+ regulatory $\mathrm{T}$ cell function [121].

\section{Increased maternal LPS-exposure during farming} enhances miR-155 release

Pregnancy in a farm environment reduces the infant's risk of atopic diseases [1-9]. TLR-mediated innate response pathways are believed to attenuate allergic Th2driven immune responses [122]. Blood cells of infants of farming-exposed mothers exhibit upregulated expression of TLR2 and TLR4 [123,124]. MiRs are fine-tuners of TLR signaling and play a crucial role in endotoxin tolerance $[125,126]$. Enhanced exposure of lipopolysaccharides (LPS) in the farm environment may result in stronger LPS-mediated TLR4 activation in monocyte/macrophages and DCs that increase expression of miR-155, miR-146a, and miR-21, crucial regulatory miRs involved in thymic Treg maturation [127-133]. Notably, activated macrophages release exosomes that can activate and recruit immune cells [134].

Placental trophoblasts, which form the interface between the maternal environment and the fetus, on stimulation secrete miR-loaded exosomes [135]. Low dose injection of LPS induces miR-155 and pre-eclampsia-like symptoms in the rat and elevated placental miR-155 in pre-eclampsia patients [136]. A time-and dose-dependent accumulation of miR-155 following LPS stimulation has been observed in human trophoblast cells [136]. LPSstimulated placenta-derived exosomal miR-release may modify fetal immune regulation [137]. Thus, enhanced prenatal LPS-induction of miR-155 may explain the higher Treg numbers in umbilicial cord blood of newborn infants of farming exposed mothers [138]. LPS-mediated miR155-expression with subsequent SOCS1 inhibition could result in robust TLR4/JAK-STAT signaling further amplifying LPS-induced miR-155 responses [139,140].

\section{Bioactive exosomal miR-155 in raw cow's milk}

Feeding raw, unpasteurized cow's milk in the first year of life exerts atopy-preventive effects, increases the number and function of FoxP3 ${ }^{+}$Tregs and decreases IgE plasma levels [1-9]. Boiling of milk degrades bioactive miRs in cow's milk [87]. Especially the whey protein fraction of milk has been implicated to mediate the atopy-protective effect of raw farm milk [3,8]. Noteworthy, miR-155 and miR-146a have not been detected in the lipid fraction of human breast milk [141]. MiR155 is expressed in highest amounts in colostrum and is a substantial component of the whey fraction of mature bovine milk $[80,81,85]$. Exosome membrane integrity is essential for the uptake of milk miRs into cultured cells

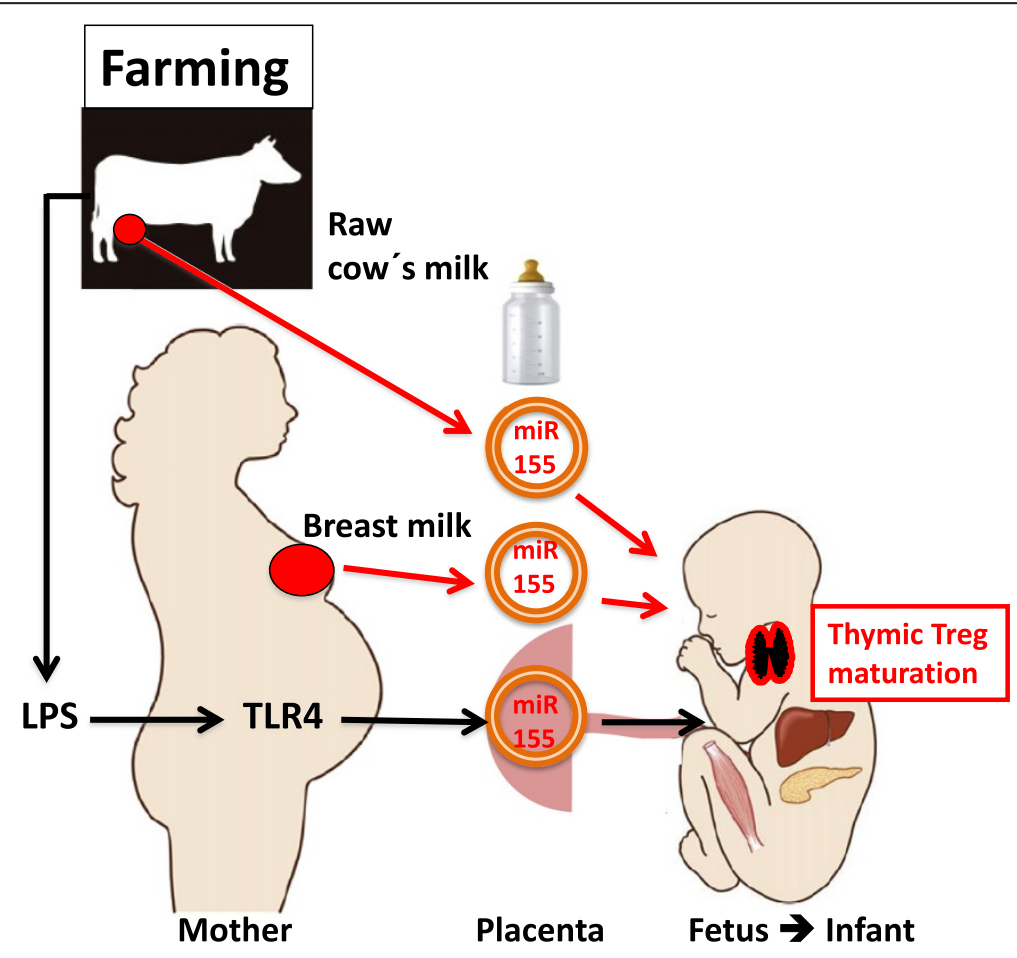

Figure 4 Perinatal scenario of milk-and LPS-induced miR-155-exosome-signaling promoting thymic Treg maturation. Fetuses and infants raised in an active farming environment are exposed to abundant sources of LPS and raw cow's milk that either stimulate or provide miR-155 compared to infants raised under civic conditions and artificial formula feeding. 
[85]. The boiling process may disrupt the lipid bilayer of milk exosomes exposing their miR content to RNasemediated degradation.

\section{Breastfeeding of non-atopic versus atopic mothers and Treg maturation}

A history of breastfeeding is associated with a reduction of the risk of asthma and atopic dermatitis [142]. Apparently, after termination of placenta-mediated signaling towards the thymus, the immunoregulatory program featured by the mammary gland may tune final miRdependent events for the proper development of the infant's immune system. We speculate that atopic mothers who exhibit lower numbers of $\mathrm{FoxP}^{+}$Tregs and who may accordingly express lower levels of FoxP3-stimulated miR-155 may provide deficient amounts of breast milk miR-155 to their infants. This may explain why atopic mothers transmit atopic diseases more frequently than atopic fathers [143-145].

\section{Artificial formula feeding and Treg maturation}

Breastfeeding compared to artificial formula feeding exerts atopy-preventive effects $[142,146,147]$. Formula production is based on bovine milk protein powder, which in comparison to raw cow's milk only contains minimal amounts of RNA [81]. Extensively hydrolyzed formula made for "atopy prevention" exhibits the lowest miR levels compared to standard formula [81,148]. According to the American Academy of Pediatrics Committee on Nutrition and Section on Allergy and Immunology, there is only "modest evidence" that the onset of atopic disease may be delayed or prevented by feeding hydrolyzed formulas compared with standard formula [146].

\section{Conclusion}

Exosomal cargo transfer plays an increasing role for intercellular communication $[149,150]$. Accumulating translational evidence sheds a new light on the potential role of milk as a transmitter of exosome-derived immune regulatory miRs for thymic Treg maturation. Milk miRs may promote the two-step selection process turning self-reactive thymocytes into stable Treg cells. TCR stimulated IL-2/STAT5 signaling may be enhanced by milk miR-155-mediated SOCS1 suppression, which augments upregulation of FoxP3. FoxP3 promotes miR-155 expression further enhancing this feed forward regulatory circuit. In a second step FoxP3 expression may be stabilized by milk-miR-mediated hypomethylation of the TSDR region of FOXP3. This hypomethylation may allow IDAX binding, which finally attracts TET2 promoting

Table 1 Translational evidence for milk-microRNA-mediated thymic Treg maturation

\begin{tabular}{|c|c|c|}
\hline Potential function of milk microRNA & Comment & References \\
\hline Milk contains abundant miRs & $\begin{array}{l}\text { From all body fluids human milk contains the highest amounts } \\
\text { of RNAs and miRs }\end{array}$ & {$[78-82,84-87,92$} \\
\hline Milk contains miR-155, miR-146a, and miR-21 & $\begin{array}{l}\text { MiR-155, miR-146a and miR-21 are crucial miRs involved in Treg } \\
\text { maturation and function }\end{array}$ & {$[79-81,84,85,87]$} \\
\hline The majority of milk's miRs are transported in exosomes & $\begin{array}{l}\text { Exosomes transfer genetic information for cell-cell communications } \\
\text { over short and long distances }\end{array}$ & {$[81,82,84-87,92]$} \\
\hline $\begin{array}{l}\text { MiR-155 is a component of colostrum and bovine whey and } \\
\text { is found to be transported in exosomes }\end{array}$ & $\begin{array}{l}\text { MiR-155 is an ancient highly conserved miR involved in immune } \\
\text { regulation }\end{array}$ & {$[84,85]$} \\
\hline $\begin{array}{l}\text { Milk exosomes are resistant against RNase-degradation and } \\
\text { acidic conditions ( } \mathrm{pH} 1-2)\end{array}$ & $\begin{array}{l}\text { Milk exosomes may survive the acidic environment of the } \\
\text { stomach. Boiling of milk destroys the biological activity of } \\
\text { milk miRs }\end{array}$ & {$[80,81,86]$} \\
\hline $\begin{array}{l}\text { Mir-155, miR-146a and miR-21 are components of human } \\
\text { blood plasma }\end{array}$ & $\begin{array}{l}\text { Milk miR-containing exosomes may be transported in circulation } \\
\text { and may reach the thymus }\end{array}$ & {$[94,95]$} \\
\hline $\begin{array}{l}\text { Bovine colostrum and bovine milk and human breast milk } \\
\text { exosomes containing miRs are taken up by cells and increase } \\
\text { cytoplasmic miR levels }\end{array}$ & $\begin{array}{l}\text { Milk-derived miRs may be taken up by exosome endocytosis in } \\
\text { recipient cells. Physical destruction of exosomal lipid bilayer } \\
\text { structure abolishes cellular miR uptake }\end{array}$ & {$[82,85,92]$} \\
\hline $\begin{array}{l}\text { Exosomal transfer is a known mechanism of communication } \\
\text { between immune cells }\end{array}$ & $\begin{array}{l}\text { Macrophages, B-cell, T cells and thymocytes communicate via } \\
\text { exosome transfer }\end{array}$ & {$[70-73,91]$} \\
\hline $\begin{array}{l}\text { Human breast milk exosomes when added to PBMCs induce } \\
\text { FoxP3 }^{+} \text {Tregs }\end{array}$ & $\begin{array}{l}\text { Breast milk miR-155 may induce the expression of FoxP3 }{ }^{+} \text {by } \\
\text { inhibiting SOCS1 signaling }\end{array}$ & [82] \\
\hline $\begin{array}{l}\text { Exosomes have been detected in the murine and human } \\
\text { thymus }\end{array}$ & $\begin{array}{l}\text { Milk-derived exosomes may augment Treg cell maturation in } \\
\text { the thymus }\end{array}$ & {$[74,91]$} \\
\hline $\begin{array}{l}\text { Murine thymic exosomes when added to thymus } \mathrm{CD}^{+}{ }^{+} \mathrm{CD} 25^{-} \\
\mathrm{T} \text { cells induce } \mathrm{CD} 4^{+} \mathrm{CD} 25^{+} \mathrm{FoxP} 3^{+} \text {Treg cells }\end{array}$ & $\begin{array}{l}\text { Milk-derived exosomes may promote Treg cell formation of } \\
\text { developing thymocytes within the human thymic medulla }\end{array}$ & {$[74,91]$} \\
\hline MiR-21 and miR-29b inhibit DNMT1 expression in T cells & $\begin{array}{l}\text { Milk miR-21 and miR-29b may promote stable expression of } \\
\text { demethylated FoxP3 and thus lineage commitment of thymic } \\
\text { Treg cells }\end{array}$ & {$[105,106]$} \\
\hline
\end{tabular}


active demethylation stabilizing FoxP3 maturation and long-term Treg lineage commitment.

Furthermore, functionally active FoxP3 Treg cells suppress the development of Th2 cell-dependent immune responses. Milk miR-155 may impair atopic sensitization by suppression of c-Maf/SHIP1-mediated IL-4 synthesis, PU.1-mediated Ig class switch to IgE as well as PU.1driven FceRI $\alpha$-chain synthesis. Thus, the milk miR system may not only augment thymic Treg maturation but may apparently prevent Th2-mediated atopic sensitization and atopic effector responses. Boiling of milk obviously destroys the miR-signaling system of milk, whereas LPS-mediated miR-155 release from stimulated maternal macrophages and trophoblast cells as well as fresh cow's milk-mediated miR-155 transfer may promote thymic Tregs maturation explaining synergistic atopypreventive effects of perinatal farm exposure (Figure 4). Milk appears to function as an evolutionarily highly conserved miR-dependent epigenetic modifyer imprinting appropriate changes required for long-term thymic FoxP3-mediated Treg differentiation. Milk-derived exosomes in synergy with thymic exosomes may play the essential role for stable maturation of $\mathrm{CD} 4{ }^{+} \mathrm{CD} 25$ ${ }^{+} \mathrm{FoxP3}^{+}$Tregs, which themselves following TCR activation produce CD73-containing exosome-like structures that mediate their suppressive activity [151].

Obviously, atopic individuals are "Treg weaklings" exhibiting lower numbers and function of FoxP3 Tregs compared to non-atopic subjects. Breast milk of atopic mothers may thus provide less FoxP3-induced miR-155 explaining the increased maternal transmission of atopic diseases compared to the lower paternal atopy transmission. Accumulating evidence supports our concept that milk's exosomal miR system may represent "the missing candidate" inducing the atopy-preventive effects of raw cow's milk consumption (Table 1). Deviations of miR processing and miR-regulated transcriptional activity may play a future role for a deeper understanding of the immunopathogenesis and treatment of atopic diseases. Future prevention of atopic diseases might be possible by addition of appropriate miR-155-enriched exosomes to artificial infant formula.

\footnotetext{
Abbreviations

CD63: Melanoma-associated antigen MLA1; CD73: Ecto-5-nucleotide enzyme; CD81: Target of antiproliferative antibody (TAPA1); DC: Dentritic cell; Der p1: Dermatophagoides pteronyssinus; DNMT: DNA methyltransferase; FceRl: IgE high affinity receptor; FCER1A: Fc fragment of IgE, high affinity I, receptor for, alpha subunit; FoxP3: Forkhead box P3 (scurfin); 5-hmc: 5Hydroxymethylcytosine (5-hmC); IDAX: Inhibitor of DVL/axin complex (CXXC4); Ig: Immunoglobulin; IgE: Immunoglobulin E; IGHE: Immunoglobulin heavy epsilon chain; IL: Interleukin; IPEX: Immune dysregulation, polyendocrinopathy, enteropathy, X-linked syndrome; LC: Langerhans cell; LDLRAP1: Low density lipoprotein receptor adaptor protein 1; LPS: Lipopolysaccharide; MFG-8: Milk fat globulin-8; 5mC: 5-Methylcytosine; miR: Micro ribonucleic acid; NIC: Notch intracellular domain; PBMC: Peripheral blood mononuclear cell; SHIP1: Src homology-2 domain-containing inositol 5-phosphatase 1; SMAD: Mothers against decapentaplegic;
}

SOCS1: Suppressor of cytokine signaling 1; STAT: Signal transducer and activator of transcription; TCR: T cell receptor; TET: Ten-eleven-translocation; TGF: Transforming growth factor; TLR: Toll-like receptor; Treg: Regulatory T cell; TSDR: Treg-specific demethylated region; TSG101: Tumor susceptibility gene 101; TSLP: Thymic stromal lymphopoietin; WAS: Wiskott-Aldrich syndrome; WASP: WAS protein.

\section{Competing interests}

The authors declare that they have no competing interests.

\section{Authors' contributions}

BCM performed translational research and wrote the manuscript. SMJ proved the data on atopy epidemiology and GS analyzed the data on exosome microRNA biology. All authors read and approved the final manuscript.

\section{Author details}

'Department of Dermatology, Environmental Medicine and Health Theory, University of Osnabrück, Sedanstrasse 115, D-49090 Osnabrück, Germany. ${ }^{2}$ Institute for Clinical Chemistry and Laboratory Medicine, University Hospital Regensburg, University of Regensburg, Josef-Strauss-Allee 11, D-93053 Regensburg, Germany.

Received: 7 December 2013 Accepted: 11 February 2014 Published: 12 February 2014

\section{References}

1. Von Mutius E, Vercelli D: Farm living: effects on childhood asthma and allergy. Nat Rev Immunol 2010, 10:861-868.

2. Perkin MR, Strachan DP: Which aspects of the farming lifestyle explain the inverse association with childhood allergy? J Allergy Clin Immunol 2006, 117:1374-1381.

3. Loss G, Apprich S, Waser M, Kneifel W, Genuneit J, Büchele G, et al: The protective effect of farm milk consumption on childhood asthma and atopy: the GABRIELA study. J Allergy Clin Immmunol 2011, 128:766-773.

4. Braun-Fahrländer $C$, von Mutius E: Can farm milk consumption prevent allergic diseases? Clin Exp Allergy 2011, 41:29-35.

5. Illi S, Depner M, Genuneit J, Horak E, Loss G, Strunz-Lehner C, et al: Protection from childhood asthma and allergy in Alpine farm environments - the GABRIEL Advanced Studies. J Allergy Clin Immunol 2012, 129:1470-1477.

6. Loss G, Bitter S, Wohlgensinger J, Frei R, Roduit C, Genuneit J, et al: Prenatal and early-life exposures alter expression of innate immunity genes: the PASTURE cohort study. J Allergy Clin Immunol 2012, 130:523-530.

7. von Mutius E: Maternal farm exposure/ingestion of unpasteurized cow's milk and allergic disease. Current Opin Gastroenterol 2012, 28:570-576.

8. Wlasiuk $G$, Vercelli $D$ : The farm effect, or: when, what and how a farming environment protects from asthma and allergic disease. Curr Opin Allergy Clin Immunol 2012, 12:461-466.

9. Lluis A, Schaub B: Lessons from the farm environment. Curr Opin Allergy Clin Immunol 2012, 12:158-163.

10. Sozanska B, Pearce N, Dudek K, Cullinan P: Consumption of unpasteurized milk and its effects on atopy and asthma in children and adult inhabitants in rural Poland. Allergy 2013, 68:644-650.

11. Lluis A, Depner M, Gaugler B, Saas P, Casaca VI, Raedler D, et al: Increased regulatory T-cell numbers are associated with farm milk exposure and lower atopic sensitization and asthma in childhood. J Allergy Clin Immunol 2013. August 28 [Epub ahead of print].

12. Palomares O, Yaman G, Azkur A, Akkoc T, Akdis M, Akdis CA: Role of Treg in immune regulation of allergic diseases. Eur J Immunol 2010, 40:1232-1240.

13. Ostroukhova M, Ray A: CD25+ T cells and regulation of allergen-induced responses. Curr Allergy Asthma Rep 2005, 5:35-41.

14. Fujita $H$, Meyer $N$, Akdis $M$, Akdis CA: Mechanisms of immune tolerance to allergens. Chem Immunol Allergy 2012, 96:30-38.

15. Kawayama T, Matsunaga K, Kaku Y, Yamaguchi K, Kinoshita T, O'Byrne PM, et al: Decreased CTLA4(+) and FoxP3(+)CD25(high)CD4(+) cells in induced sputum from patients with mild atopic asthma. Allergol Int 2013, 62:203-213.

16. Stelmaszczyk-Emmel A, Zawadzka-Krajewska A, Szypowska A, Kulus M, Demkow U: Frequency and activation of CD4 + CD25 FoxP3+ regulatory T cells in peripheral blood from children with atopic allergy. Int Arch Allergy Immunol 2013, 162:16-24.

17. Hinz D, Simon JC, Maier-Simon C, Milkova L, Röder S, Sack U, et al: Reduced maternal regulatory $\mathrm{T}$ cell numbers and increased T helper type 2 
cytokine production are associated with elevated levels of immunoglobulin E in cord blood. Clin Exp Allergy 2010, 40:419-426.

18. Brunkow ME, Jeffery EW, Hjerrild KA, Paeper B, Clark LB, Yasayko SA, et al: Disruption of a new forkhead/winged-helix protein, scurfin, results in the fatal lymphoproliferative disorder of the scurfy mouse. Nat Genet 2001, 27:68-73.

19. Barzaghi F, Passerini L, Bacchetta R: Immune dysregulation, polyendocrinopathy, enteropathy, X-linked syndrome: a paradigm of immunodeficiency with autoimmunity. Front Immunol 2012, 3:211.

20. Humblet-Baron S, Sather B, Anover S, Becker-Herman S, Kasprowicz DJ, Khim S, et al: Wiskott-Aldrich syndrome protein is required for regulatory $\mathrm{T}$ cell homeostasis. J Clin Invest 2007, 117:407-418.

21. Marangoni F, Trifari S, Scaramuzza S, Panaroni C, Martino S, Notarangelo LD, et al: WASP regulates suppressor activity of human and murine CD4(+) CD25(+)FoxP3(+) natural regulator T cells. J Exp Med 2007, 204:369-380.

22. Maillard MH, Cotta-de-Almeida V, Takeshima F, Nguyen DD, Michetti $P$, Nagler $C$, et al: The Wiskott-Aldrich syndrome protein is required for the function of CD4(+)CD25(+)FoxP3(+) regulatory T cells. J Exp Med 2007, 204:381-391.

23. Kanjarawi R, Dy M, Bardel E, Sparwasser T, Dubois B, Mecheri S, et al: Regulatory CD4 + FoxP3+ T cells control the severity of anaphylaxis. PLoS One 2013, 8:e69183.

24. Leech MD, Benson RA, De Vries A, Fitch PM, Howie SE: Resolution of Der p1-induced allergic airway inflammation is dependent on $\mathrm{CD} 4+\mathrm{CD} 25+$ FoxP3+ regulatory cells. J Immunol 2007, 179:7050-7058.

25. Akdis CA, Akdis M: Mechanisms and treatment of allergic disease in the big picture of regulatory T cells. J Allergy Clin Immunol 2009, 123:735-746.

26. Sakaguchi S, Miyara M, Costantino CM, Hafler DA: FOXP3+ regulatory T cells in the human immune system. Nat Rev Immunol 2010, 10:490-500.

27. Paik Y, Dahl M, Fang D, Calhoun K: Update: the role of FoxO3 in allergic disease. Curr Opin Otolaryngol Head Neck Surg 2008, 16:275-279.

28. Hsieh CS, Lee HM, Lio WC: Selection of regulatory T cells in the thymus. Nat Rev Immunol 2012, 12:157-167.

29. Fontenot JD, Rasmussen JP, Williams LM, Dooley JL, Farr AG, Rudensky AY: Regulatory $T$ cell lineage specification by the forkhead transcription factor foxp3. Immunity 2005, 22:329-341.

30. Buckner JH, Ziegler SF: Functional analysis of FOXP3. Ann N Y Acad Sci 2008, 1143:151-169.

31. Hori S, Nomura T, Sakaguchi S: Control of regulatory T cell development by the transcription factor Foxp3. Science 2003, 299:1057-1061.

32. Yagi H, Nomura T, Nakamura K, Yamazaki S, Kitawaki T, Hori S, et al: Crucial role of FOXP3 in the development and function of human CD25 + CD4 regulatory T cells. Int Immunol 2004, 16:1643-1656.

33. Ziegler SF: FOXP3: of mice and men. Annu Rev Immunol 2006, 24:209-226.

34. Lee HM, Bautista JL, Hsieh CS: Thymic and peripheral differentiation of regulatory T cells. Adv Immunol 2011, 112:25-71.

35. Bilate AM, Lafaille JJ: Induced CD4 + Foxp3+ regulatory T cells in immune tolerance. Annu Rev Immunol 2012, 30:733-758.

36. Baecher-Allan C, Viglietta V, Hafler DA: Human CD4 + CD25+ regulatory T cells. Semin Immunol 2004, 16:89-98.

37. Hori S, Sakaguchi S: Foxp3: a critical regulator of the development and function of regulatory T cells. Microbes Infect 2004, 6:745-751.

38. Zhang $L$, Zhao $Y$ : The regulation of Foxp3 expression in regulatory CD4 (+)CD25(+)Tcells: multiple pathways on the road. J Cell Physiol 2007, 211:590-597.

39. Campbell DJ, Ziegler SF: FOXP3 modifies the phenotypic and functional properties of regulatory T cells. Nat Rev Immunol 2007, 7:305-310.

40. Marson A, Kretschmer K, Frampton GM, Jacobsen ES, Polansky JK, Maclsaac $\mathrm{KD}$, et al: Foxp3 occupancy and regulation of key target genes during T-cell stimulation. Nature 2007, 445:931-935.

41. Fontenot JD, Dooley JL, Farr AG, Rudensky AY: Developmental regulation of Foxp3 expression during ontogeny. J Exp Med 2005, 202:901-906.

42. Watanabe N, Wang YH, Lee HK, Ito T, Wang YH, Cao W, et al: Hassall's corpuscles instruct dendritic cells to induce $C D 4+C D 25+$ regulatory $T$ cells in human thymus. Nature 2005, 436:1181-1185.

43. Jiang Q, Su H, Knudsen G, Helms W, Su L: Delayed functional maturation of natural regulatory $T$ cells in the medulla of postnatal thymus: role of TSLP. BMC Immunol 2006, 7:6.

44. Fontenot JD, Gavin MA, Rudensky AY: FoxP3 programs the development and function of CD4 + CD25+ regulatory T cells. Nat Immunol 2003, 4:330-336.
45. Del Papa B, Sportoletti P, Cecchini D, Rosati E, Balucani C, Balsdoni S, et al: Notch1 modulates mesenchymal stem cells mediated regulatory T-cell induction. Eur J Immunol 2013, 43:182-187.

46. Xiao C, Rajewsky K: MicroRNA control in the immune system: basic principles. Cell 2009, 136:26-36.

47. Kohlhaas S, Garden OA, Scudamore C, Turner M, Okkenhaug K, Vigorito E: Cutting edge: the FoxP3 target miR-155 contributes to the development of regulatory T cells. J Immunol 2009, 182:2578-2582.

48. Josefowicz SZ, Lu LF, Rudensky AY: Regulatory T cells: menchanisms of differentiation and function. Annu Rev Immunol 2012, 30:531-564.

49. Povoleri GA, Scotta C, Nova-Lamperti EA, John S, Lombardi G, Afzali B: Thymic versus induced regulatory $T$ cells - who regulates the regulators? Front Immunol 2013, 4:169.

50. Cobb BS, Hertweck A, Smith J, O'Connor E, Graf D, Cook T, et al: A role for Dicer in immune regulation. J Exp Med 2006, 203:2519-2527.

51. Zheng Y, Josefowicz SZ, Kas A, Chu TT, Gavin MA, Rudensky AY: Genome-wide analysis of FoxP3 target genes in developing and mature regulatory $\mathrm{T}$ cells. Nature 2007, 445:936-940

52. Lio CW, Hsieh CS: A two-step process for thymic regulatory $\mathrm{T}$ cell development. Immunity 2008, 28:100-111.

53. Burchill MA, Yang J, Vang KB, Moon JJ, Chu HH, Lio CW, et al: Linked T cell receptor and cytokine signaling govern the development of the regulatory T cell repertoire. Immunity 2008, 28:112-121.

54. Vang KB, Yang J, Mahmud SA, Burchill MA, Vegoe AL, Farrar MA: IL-2, -7, and -15 but not stromal lymphopoetin, redundantly govern CD4 + FoxP3 + regulatory T cell development. J Immunol 2008, 181:3285-3290.

55. Lu LF, Thai TH, Calado D, Chaudhry A, Kubo M, Tanaka K, et al: Foxp3dependent microRNA155 confers competitive fitness to regulatory $T$ cells by targeting SOCS1 protein. Immunity 2009, 30:80-91.

56. Lu LF, Boldin MP, Chaudhry A, Lin LL, Taganov KD, Hanada T, et al: Function of miR-146a in controlling Treg cell-mediated regulation of Th1 responses. Cell 2010, 142:914-929.

57. Rouas R, Fayyad-Kazan H, El Zein N, Lewalle P, Rothé F, Simion A, et al: Human natural Treg microRNA signature: role of microRNA-31 and microRNA-21 in FOXP3 expression. Eur J Immunol 2009, 39:1608-1618.

58. Liston A, Lu LF, O'Carroll D, Tarakhovsky A, Rudensky AY: Dicer-dependent microRNA pathway safeguards regulatory T cell function. J Exp Med 2008, 205:1993-2004.

59. Zhou X, Jeker LT, Fife BT, Thu S, Anderson MS, McManus MT, et al: Selective miRNA disruption in T reg cells leads to uncontrolled autoimmunity. J Exp Med 2008, 205:1983-1991.

60. Yao R, Ma YL, Liang W, Li HH, Ma ZJ, Yu X, et al: MicroRNA-155 modulates Treg and Th17 cells differentiation and Th17 cell function by targeting SOCS1. Plos One 2012, 7:e46082.

61. Zhu J, Yamane H, Cote-Sierra J, Guo L, Paul WE: GATA-3 promotes Th2 responses through three different mechanisms: induction of Th2 cytokine production, selective growth of Th2 cells and inhibition of Th1 cell-specific factors. Cell Res 2006, 16:3-10.

62. Rodriquez A, Vigorito E, Clare S, Warren MV, Couttet P, Soond DR, et al: Requirement of bic/microRNA-155 for normal immune function. Science 2007, 316:608-611

63. Thai TH, Calado DP, Casola S, Ansel KM, Xiao C, Xue Y, et al: Regulation of the germinal center response by microRNA-155. Science 2007, 316:604-608.

64. Valadi H, Ekstöm K, Bossios A, Sjöstrand M, Lee JJ, Lötvall JO: Exosomemediated transfer of mRNA and microRNAs is novel mechanism of genetic exchange between cells. Nat Cell Biol 2007, 9:654-659.

65. Liang H, Huang L, Cao J, Zen K, Chen X, Zhang CY: Regulation of mammalian gene expression by exogeneous microRNAs. Wiley Interdiscip Rev RNA 2012, 3:733-742

66. Chen X, Liang H, Zhang J, Zen K, Thang CY: Secreted microRNAs: a new form of intercellular communication. Trends Cell Biol 2012, 22:125-132.

67. Ludwig AK, Giebel B: Exosomes: small vesicles participating in intercellular communication. Int I Biochem Cell Biol 2012, 44:11-15.

68. Ambros $V$ : The functions of animal microRNAs. Nature 2004, 431:350-355.

69. Chen $X$, Liang $H$, Zhang J, Zen $\mathrm{K}$, Zhang $\mathrm{CY}$ : Horizontal transfer of microRNAs: molecular mechansism and clinical applications. Protein Cell 2012, 3:28-37.

70. Raposo G, Nijman HW, Stoorvogel W, Liejendecker R, Harding CV, Melief CJ, et al: B lymphocytes secrete antigen-presenting vesicles. J Exp Med 1996 183:1161-1172. 
71. Mittelbrunn M, Guitiérrez-Vásquez C, Villarroya-Beltri C, González S, SánchezCabo F, González MA, et al: Unidirectional transfer of microRNA-loaded exosomes from T cells to antigen-presenting cells. Nat Commun 2011, 2:282.

72. Mittelbrunn M, Sanchez-Madrid F: Intercellular communication: diverse structures for exchange of genetic information. Nat Rev Mol Cell Biol 2012, 13:328-335.

73. Gutiérrez-Vázquez C, Villarroya-Beltri C, Mittelbrunn M, Sánchez-Madrid F: Transfer of extracellular vesicles during immune cell-cell interactions. Immunol Rev 2013, 251:125-142.

74. Skogberg G, Gudmundsdottir J, van der Post S, Dandström K, Bruhn S, Benson $M$, et al: Characterization of human thymic exosomes. PLoS One 2013, 8:e67554.

75. Melnik BC, John SM, Schmitz G: Milk is not just food but most likely a genetic transfection system activating $\mathrm{mTORC} 1$ signaling for postnatal growth. Nutr J 2013, 12:103.

76. Zhang L, Hou D, Chen X, Li D, Zhu L, Zhang Y, et al: Exogenous plant MIR168a specifically targets mammalian LDLRAP1: evidence of cross-kingdom regulation by microRNA. Cell Res 2012, 22:107-126.

77. Dickinson B, Zhang Y, Petrick JS, Heck G, Ivashuta S, Marshall WS: Lack of detectable oral bioavailability of plant microRNAs after feeding in mice. Nat Biotechnol 2013, 31:965-967.

78. Weber JA, Baxter DH, Zhang S, Huang DY, Huang KH, Lee MJ, et al: The microRNA spectrum in 12 body fluids. Clin Chem 2010, 56:1733-1741.

79. Hata T, Murakami K, Nakatani H, Yamamoto Y, Matsuda T, Aoki N: Isolation of bovine milk-derived microvesicles carrying mRNAs and microRNAs. Biochem Biophys Res Commun 2010, 396:528-533.

80. Chen X, Gao C, Li H, Huang L, Sun Q, Dong Y, et al: Identification and characterization of microRNAs in raw milk during different periods of lactation, commercial fluid, and powdered milk products. Cell Res 2010, 20:1128-1137.

81. Izumi H, Kosaka N, Shimizu T, Sekine K, Ochiya T, Takase M: Bovine milk contains microRNA and messenger RNA that are stable under degradative conditions. J Dairy Sci 2012, 95:4831-4841.

82. Admyre C, Johansson SM, Qazi KR, Filén JJ, Lahesmaa R, Norman M, et al: Exosomes with immune modulatory features are present in human breast milk. J Immunol 2007, 179:1969-1978.

83. Reinhardt TA, Lippolis JD, Nonnecke BJ, Sacco RE: Bovine milk exosome proteome. J Proteomics 2012, 75:1486-1492.

84. Izumi H, Kosaka N, Shimizu T, Sekine K, Ochiya T, Takase M: Purification of RNA from milk whey. Methods Mol Biol 2013, 1024:191-201.

85. Sun Q, Chen X, Yu J, Zen K, Zhang CY, Li L: Immune modulatory function of abundant immune-related microRNAs in microvesicles from bovine colostrum. Protein Cell 2013, 4:197-210.

86. Kosaka N, Izumi H, Sekine K, Ochiya T: microRNA as a new immuneregulatory agent in breast milk. Silence 2010, 1:7.

87. Zhou Q, Li M, Wang X, Li Q, Wang T, Zhu Q, et al: Immune-related microRNAs are abundant in breast milk exosomes. Int J Biol Sci 2012 , 8:118-123.

88. van Niel G, Raposo G, Candalh C, Boussac M, Hershberg R, Cerf-Benussan N, et al: Intestinal epithelial cells secrete exosome-like vesicles. Gastroenterology 2001, 121:337-349

89. Caby MP, Lankar D, Vincendeau-Scherrer C, Raposo G, Bonnerot C: Exosomallike vesicles are present in human blood plasma. Int Immunol 2005, $17: 879-887$

90. Corrado C, Raimondo S, Chiesi A, Ciccia F, De Leo G, Alessandro R: Exosomes as intercellular signaling organelles involved in health and disease: basic science and clinical applications. Int J Mo/ Sci 2013, 14:5338-5366.

91. Wang GJ, Liu Y, Qin A, Shah SV, Deng ZB, Xiang X, et al: Thymus exosomes-like particles induce regulatory T cells. J Immunol 2008, 181:5242-5248.

92. Lässer C, Alikhani VS, Ekström K, Eldh M, Pareds PT, Bossios A, et al: Human saliva, plasma and breast milk exosomes contain RNA: uptake by macrophages. J Trans/ Med 2011, 9:9.

93. Boismenu R, Rhein M, Fischer WH, Havran WL: A role for CD81 in early T cell development. Science 1996, 271:198-200.

94. Hulsmans M, Holvoet P: MicroRNA-containing microvesicles regulating inflammation in association with atherosclerotic disease. Cardiovasc Res 2013, 100:7-18.

95. Olivieri F, Spazzafumo L, Santini GLazzarini R, Albertini MC, Rippo MR, et al: Age-related differences in the expression of circulating microRNAs: miR-21 a new circulating marker of inflammaging. Mech Ageing Dev 2012, 133:675-685.

96. Tam W: Identification and characterization of human BIC, a gene on chromosome 21 that encodes a noncoding RNA. Gene 2001, 274:157-167.

97. Toker A, Engelbert D, Garg G, Polansky JK, Floess S, Miyao T, et al: Active demethylation of the Foxp3 locus leads to the generation of stable regulatory T cells within the thymus. J Immuno/ 2013, 190:3180-3188.

98. Polansky JK, Schreiber L, Thelemann C, Ludwig L, Krüger M, Baumgrass $R$, et al: Methylation matters: binding of Ets-1 to the demethylated Foxp3 gene contributes to the stabilization of FoxP3 expression in regulatory T cells. J Mol Med (Berl) 2010, 88:1029-1040.

99. Hinz D, Bauer M, Röder S, Olek S, Huehn J, Sack U, LINA study group, et al. Cord blood Tregs with stable FOXP3 expression are influenced by prenatal environment and associated with atopic dermatitis at the age of one year. Allergy 2012, 67:380-389.

100. Koh KP, Rao A: DNA methylation and methylcytosine oxidation in cell fate decisions. Curr Opin Cell Biol 2013, 25:152-161.

101. Ko M, Bandukwala HS, Chavez L, Aijö T, Pastor WA, Segal MF, et al: Modulation of TET2 expression and 5-methylcytosine oxidation by the CXXC domain protein IDAX. Nature 2013, 497:122-126.

102. Dunican DD, Pennings S, Meeha RR: The CXXC-TET bridge-mind the methylation gap! Cell Res 2013, 23:973-974.

103. Lal G, Bromberg JS: Epigenetic mechanisms of regulation of Foxp3 expression. Blood 2009, 114:3727-3735.

104. Cheng J, Guo S, Chen S, Mastriano SJ, Liu C, D'Alessio AC, et al: An extensive network of TET2-targeting microRNAs regulates malignant hematopoiesis. Cell Rep 2013, 5:471-481.

105. Pan W, Zhu S, Yuan M, Cui H, Wang L, Luo X, et al: MicroRNA-21 and microRNA-148a contribute to DNA hypomethylation in Lupus CD4+ T cells by directly and indirectly targeting DNA methyltransferase 1 . $\mathrm{J}$ Immunol 2010, 184:6773-6781.

106. Qin H, Zhu X, Liang J, Wu J, Yang Y, Wang S, et al: MicroRNA-29b contributes to DNA hypomethylation of CD4+ T cells in systemic lupus erythematodes by indirectly targeting DNA methyltransferase 1. J Dermatol Sci 2013, 69:61-67.

107. Ho IC, Hodge MR, Rooney JW, Glimcher LH: The proto-oncogene c-maf is responsible for tissue-specific expression of interleukin-4. Cell 1996, 85:973-983.

108. Kim Jl, Ho IC, Grusby MJ, Glimcher LH: The transcription factor c-Maf controls the production of interleukin- 4 but not other Th2 cytokines. Immunity 1999, 10:745-751.

109. Vigorito E, Kohlhaas S, Lu D, Leyland R: miR-155: an ancient regulator of the immune system. Immunol Rev 2013, 253:146-157.

110. Corey SJ, Mehta HM, Stein PL: Two SHIPs passing in the middle of the immune system. Eur J Immunol 2012, 42:1681-1684.

111. Srivastava N, Sudan R, Kerr WG: Role of inositol poly-phosphatases and their targets in T cell biology. Front Immunol 2013, 4:288.

112. Collazo MM, Paraiso KH, Park MY, Hazen AL, Kerr WG: Lineage extrinsic and intrinsic control of immunoregulatory cell numbers by SHIP. Eur J Immunol 2012, 42:1785-1795.

113. O'Connell RM, Chaudhuri AA, Rao DS, Baltimore D: Inositol phosphatase SHIP1 is a primary target of miR-155. Proc Natl Acad Sci U S A 2009, 106:7113-7118.

114. Vigorioto E, Perks KL, Abreu-Goodger C, Bunting S, Xiang Z, Kohlhaas S, et al: microRNA-155 regulates the generation of immunoglobulin class-switched plasma cells. Immunity 2007, 27:847-859.

115. Stütz AM, Woisetschläger M: Functional synergism of STAT6 with either NF-kappaB or PU.1 to mediate IL-4-induced activation of the lgE germline gene transcription. J Immunol 1999, 163:4383-4391.

116. Stütz AM, Hoeck J, Natt F, Cuenoud B, Woisetschläger M: Inhibition of interleukin-4- and CD40-induced IgE germline gene promoter activity by 2'-aminoethoxy-modified triplex-forming oligonucleotides. J Biol Chem 2001, 276:11759-11765.

117. Gauchat JF, Lebman DA, Coffman RL, Gascan H, de Vries JE: Stucture and expression of germline epsilon transcripts in human B cells induced by interleukin 4 to switch to IgE production. J Exp Med 1990, 172:463-473.

118. Nishiyama C: Molecular mechanism of allergy-related gene regulation and hematopoietic cell development by transcription factors. Biosci Biotechnol Biochem 2006, 70:1-9.

119. Choi SY, Sohn MH, Kwon BC, Kim KE: CTLA-4 expression in T cell of patients with atopic dermatitis. Pediatr Allergy Immunol 2005, 16:422-427. 
120. Sonkoly E, Janson P, Majuri ML, Savinko T, Fyhrquist N, Eidsmo L, et al: MiR-155 is overexpressed in patients with atopic dermatitis and modulates T-cell proliferative responses by targeting cytotoxic T lymphocyte-associated antigen 4. J Allergy Clin Immunol 2010, 126:581-589.

121. Wing K, Onishi Y, Prieto-Martin P, Yamaguchi T, Miyara M, Fehervari Z, et al: CTLA-4 control over Foxp3+ regulatory T cell function. Science 2008 322:271-275.

122. Prescott SL: Effects of early cigarette smoke exposure on early immune development and respiratory diseases. Paediatr Respir Rev 2008, 9:3-10.

123. Lauener $R$, Birchler $T$, Adamski J, Braun-Fahrländer C, Bufe A, Herz U, et al: Expression of CD14 and Toll-like receptor 2 in farmers and non-farmers children. Lancet 2002, 360:465-466.

124. Ege MJ, Bieli C, Frei R, van Strien RT, Riedler J, Ublagger E, et al: Prenatal farm exposure is related to the expression of receptors of the innate immunity and to atopic sensitization in schoo-age children. J Allergy Clin Immunol 2006, 117:817-823.

125. O'Neill LA, Sheedy FJ, McCoy CE: MicroRNAs: the fine-tuners of Toll-like receptor signalling. Nat Rev Immunol 2011, 11:163-175.

126. Nahid MA, Satoh M, Chan EK: MicroRNA in TLR signaling and endotoxin tolerance. Cell Mol Immunol 2011, 8:388-403.

127. O'Connell RM, Taganov KD, Boldin MP, Chneg G, Baltimore D: MicroRNA-155 is induced during the macrophage inflammatory response. Proc Natl Acad Sci U S A 2007, 104:1604-1609.

128. Tili E, Michaille JJ, Cimino A, Costinean S, Dumitru CD, Adair B, et al: Modulation of miR-155 and miR-125b levels following lipopolysaccharide/ TNF-alpha stimulation and their possible roles in regulating the response to endotoxin shock. J Immunol 2007, 179:5082-5089.

129. McCoy CE, Sheedy FJ, Qualls JE, Doyle SL, Quinn SR, Murray PJ, et al: IL-10 inhibits miR-155 induction by toll-like receptors. J Biol Chem 2010, 285:20492-20498.

130. Taganov KD, Boldin MP, Chang KJ, Baltimore D: NF-kappaB-dependent induction of microRNA miR-146, an inhibitor targeted to signaling proteins of innate immune responses. Proc Natl Acad Sci U S A 2006, 103:12481-12486.

131. Sheedy FJ, Palsson-McDermott E, Hennessy EJ, Martin C, O'Leary JJ, Ruan Q, et al: Negative regulation of TLR4 via targeting of the proinflammatory tumor suppressor PDCD4 by the microRNA miR-21. Nat Immunol 2010, 11:141-147.

132. Worm J, Stenvang J, Petri A, Frederiksen KS, Obad S, Elmén J, et al: Silencing of microRNA-155 in mice during acute inflammatory response leads to derepression of c/ebp beta and down-regulation of G-CSF. Nucleic Acid Res 2009, 37:5784-5792

133. Ceppi M, Peireira PM, Dunand-Sauthier I, Barras E, Reith W, Santos MA, et al: MicroRNA-155 modulates the interleukin-1 signaling pathway in activated human monocyte-derived dendritic cells. Proc Natl Acad Sci U S A 2009, 106:2735-2740.

134. Singh PP, Smith VL, Karakousis PC, Schorey JS: Exosomes isolated from mycobacteria-infected mice or cultured macrophages can recruit and activate immune cells in vitro and in vivo. J Immunol 2012, 189:777-785.

135. Delorme-Axford E, Donker RB, Mouillet JF, Chu T, Bayer A, Quyang Y, et al: Human placental trophoblasts confer viral resistance to recipient cells. Proc Natl Acad Sci U S A 2013, 110:12048-12053.

136. Dai Y, Diao Z, Sun H, Li R, Qiu Z, Hu Y: MicroRNA-155 is involved in the remodeling of the human-trophoblast-derived HTR-8/SVneo cells induced by lipopolysaccharides. Hum Reprod 2011, 26:1882-1891.

137. Bullerdiek J, Flor I: Exosome-delivered microRNAs of "chromosome 19 microRNA cluster" as immunomodulators in pregnancy and tumorigenesis. Mol Cytogenet 2012, 5:27.

138. Schaub B, Liu J, Höppler S, Schleich I, Huehn J, Olek S, et al: Maternal farm exposure modulates neonatal immune mechansims through regulatory T cells. J Allergy Clin Immunol 2009, 123:774-782.

139. Nakagawa R, Naka T, Tsutsui H, Fujimotot M, Kimura A, Abe T, et al: SOCS-1 participates in negative regulation of LPS responses. Immunity 2002 17:677-687.

140. Kinjyo I, Hanada T, Inagaki-Ohara K, Mori H, Aki D, Ohishi M, et al: SOCS1/ $J A B$ is a negative regulator of LPS-induced macrophage activation. Immunity 2002, 17:583-591.

141. Munch EM, Harris AA, Mohammad M, Benham AL, Pejerrey SM, Showalter $L$, et al: Transcriptome profiling of microRNA by next-gen deep sequencing reveals known and novel species in the lipid fraction of human breast milk. PLoS One 2013, 8:e50564.
142. Ip S, Chung M, Raman G, Chew P, Magula N, De Vine D, et al: Breastfeeding and maternal and infant health outcomes in developed countries. Evid Rep Technol Assess (Full Rep) 2007, 153:1-186.

143. Diepgen $T L$, Blettner $M$ : Analysis of familial aggregation of atopic eczema and other diseases by odds ratio regression models. J Invest Dermatol 1996, 106:977-981.

144. Dold S, Wjst M, von Mutius E, Reitmeir P, Stiepel E: Genetic risk for asthma, allergic rhinitis, and atopic dermatitis. Arch Dis Child 1992, 67:1018-1022.

145. Ruiz RG, Kemeny DM, Price JF: Higher risk of infantile atopic dermatitis from maternal atopy than from paternal atopy. Clin Exp Allergy 1992 22:762-766.

146. Greer FR, Sicherer SH, Burks W, American Academy of Pediatrics Committee on Nutrition and Section on Allergy and Immunology: Effects of early nutritional interventions on the development of atopic disease in infants and children: the role of maternal dietary restriction, breastfeeding, timing of introduction of complementary foods, and hydrolyzed formulas. Pediatrics 2008, 121:183-191.

147. Lee SY, Kang MJ, Kwon JW, Parks KS, Hong SJ: Breast feeding might have protective effects on atopy in children with the CD14C-159CT/CC genotype. Allergy Asthma Immunol Res 2013, 5:239-241.

148. Simpson RJ, Lim JW, Moritz RL, Mathivanan S: Exosomes: proteomic insights and diagnostic potential. Expert Rev Proteomics 2009, 6:267-283.

149. Choi DS, Kim DK, Kim YK, Gho YS: Proteomics, transcriptomics and lipidomics of exosomes and ectosomes. Proteomics 2013, 13:1554-1571.

150. Kosaka N, Yoshioka Y, Hagiwara K, Tominaga N, Katsuda T, Ochiya T: Trash or treasure: extracellular microRNAs and cell-to-cell communication. Front Genet 2013, 4:173.

151. Smyth LM, Ratnasothy K, Tsang JY, Boardman D, Warley A, Lechler $R$, et al: CD73 expression on extracellular vesicles derived from CD4 + CD25 + FoxP3+ T cells contributes to their regulatory function. Eur J Immunol 2013, 43:2430-2440.

doi:10.1186/1479-5876-12-43

Cite this article as: Melnik et al:: Milk: an exosomal microRNA transmitter promoting thymic regulatory $T$ cell maturation preventing the development of atopy? Journal of Translational Medicine 2014 12:43.

\section{Submit your next manuscript to BioMed Central and take full advantage of:}

- Convenient online submission

- Thorough peer review

- No space constraints or color figure charges

- Immediate publication on acceptance

- Inclusion in PubMed, CAS, Scopus and Google Scholar

- Research which is freely available for redistribution

Submit your manuscript at www.biomedcentral.com/submit
C Biomed Central 